\title{
The Influence of Prior Accounting Learning, Class Attendance, Learning Behavior and Interest in Reading Towards the Understanding of Accounting
}

\author{
Ayu Chairina Laksmi ${ }^{1}$, Faris Asyrof Al Fatih ${ }^{2}$ \\ \{ayucl@uii.ac.id ${ }^{1}$, faris.asyrof@gmail.com² \\ ${ }^{1,2}$ Universitas Islam Indonesia, Yogyakarta, Indonesia
}

\begin{abstract}
Understanding of accounting is important for undergraduate students who wish to graduate and become accounting professionals. Students learn on their own. This study investigates the influence of prior accounting learning, class attendance, learning behavior, and interest in reading towards accounting understanding. The population of this study is accounting students from the class of 2014 in Daerah Istimewa Yogyakarta, Indonesia represented by UII, UGM, and UMY students, and a purposive sampling method was employed. The data collection method used was a survey by distributing online questionnaires. The data collected were analyzed using multiple regression analysis. The results of this study show that prior accounting learning, class attendance, learning behavior, interest in reading have a significant and positive influence on accounting understanding among undergraduate accounting students in Daerah Istimewa Yogyakarta.
\end{abstract}

Keywords: Prior accounting learning, class attendance, learning behavior, reading interest, accounting understanding, Indonesia

\section{Introduction}

Accounting can be defined as a recording system for business transactions report in financial terms, to be used by the interested parties as the basis of control, performance assessment, and decision making [1]. As a science, accounting has several specialized subjects such as environmental accounting, managerial accounting, accounting information systems, public sector accounting, audit, accounting theory, forensic accounting, and many more. Thus, the education -including accounting and all the derivatives of accounting- would never exist if there were no understanding of accounting knowledge.

Wasistha [2] explained that there are two competencies level in accounting compulsory for chartered accountants. The levels are professional level and foundation level. Professional level consists of application, evaluation, and integration; while for foundation level, they are financial accounting, cost and management accounting, auditing, information system, taxation, business law, financial management, general management, and economics. It would mean that accounting students should pass and understand accounting-related subjects to be considered as a qualified accountant. Moreover, higher education institutions are expected to educate students to be expert in academic, but also in technical-analytical ability in humanistic skills (which consist of humanistic concept in social life, also be responsible toward humanity values and be responsible toward the others) as well as professional skills (the ability to do the job based on academic knowledge), in order to get a 
greater opportunity in professional area [3]. Therefore, it is important to investigate factors in achieving accounting understanding.

According to Lunenburg [4], students' behavior in learning also takes part in the factor that impacts them in understanding and performing accounting. Similarly, Suwardjono [5] asserted that students' learning behavior consists of the habit of following the learning activities, the habit of literacy, attendance in the library, and the habit of preparing the exam. Furthermore, class attendance is also important to increase the understanding of accounting. Clay and Breslow [6] explained that the student non-attendance reasons vary from no expectation to learn, no need to attend since they have already understood, no alignment between assignments and examination, and also no good delivery of materials from lecturers.. Yet, there are some benefits if students attend the class. Based on the research by Jameel and Hamdan [7], it is believed that students will memorize the study materials longer if they attend the class since they can participate in debates and share their thoughts; they also can increase critical thinking by enhancing communication skills especially in speaking, listening, and presentation skills; they also able to shortcut the self-study learning if they come in regular basis class. For the abovementioned reasons, it is can be concluded that both sides need to pay attention to the importance of attending the class.

Prior accounting learning can also be considered as one of the factors in understanding accounting. According to Agustina and Yanti [8], a high school background is the students' study experience in senior high school. In Indonesia, senior high school students can choose to study natural science or social science as their major. Senior high school students from social science normally undertake accounting subjects; hence they already have some accounting knowledge prior to studying accounting for their undergraduate degree. Those who have already understand must be the graduates from social science in high school or accounting students in vocational high school, and those who do not understand can be assumed that they must be the graduates of natural science in high school or other than accounting students at vocational high schools [9].

Based on the abovementioned background, the objective of this study is to investigate the influence of prior accounting learning, class attendance, learning behavior, and reading interest towards students' understanding in accounting. This study is conducted based on previous research by Pratiwi [10], Jameel and Hamdan [7], and Agustina and Yanti [8]. This study contributes to the accounting education body of knowledge by providing insight into the factors influencing undergraduate students' understanding of accounting. It is certainly helpful for the accounting higher education institutions to find out about the factors affecting students' understanding in order to build a better curriculum and also the education system.

\section{Literature review}

This section discusses the previous literature and theory underpining this study.

\subsection{Prior accounting understanding}

Education is important for a human being's life. According Bhoje [11] academic or education is defined as a purposive, conscious or unconscious, psychological, sociological, scientific and philosophical process, which brings about the development of the individual to the fullest extent and also the maximum development of society in such a way that both 
enjoy maximum happiness and prosperity. Education comes from the influence of surroundings in someone's life to make changes in behavior, mind, and attitude. Education commonly is related to the formal one. Formal education is an education in an academic institution that is gradually and regularly continuous using clear terms and conditions. The teachers' objective itself is to enrich the character, knowledge, and prepare someone's readiness to be able and skillful in the professional world [12].

Education is not only about the transfer of knowledge but also a process on how a human becomes a truly human being by using education. Yoesoef (2013) explained that education is about a process in learning, a social process, and a process of humanizing the human being. As a consequence, education can also change and develop people' attitudes and behavior.

Educational background is experiences obtained from academic programs in the past and largely obtained in high school. If a person has an accounting background or undertook accounting subjects in high school, then that person can be assumed to have better accounting understanding than those who do not have the experience before. Without an accounting educational background, it is quite hard to learn and understand accounting [8]. They also believed that academic experiences help someone's efficiency process of study. Previous research shows that, there are students who enroll in an undergraduate accounting degree but have no prior accounting learning during their time in high school [9]. Without having prior knowledge and understanding of basic accounting, students may find it hard to understand accounting subjects in the undergraduate level. In short, different prior accounting learning can create different understanding of accounting among undergraduate students.

\subsection{Class attendance}

Attendance in-class activity is essential to enhance the understanding of materials or subjects being studied. Not only because it can enhance someone's memory for some knowledge through specific events that he or she attend, but also because some higher education institutions make attendance as mandatory. Yet, it is hard to make students understand to be present in the class. According to Prihartanto [13] there are some factors that affect students to not attend the class, they are:

1. Internal factors: positive perspective about skipping the classes, not feeling guilty about skipping the classes, too lazy to attend the class, impulsive, rationalization about not attend the class, overslept, too late to come to the class, there are some positive sides of skipping the class, also a habit.

2. External factors: the easiness of asking classmates to sign the attendance, modeling, situational factors, someone's affection to not to attend the class, lecturers, do other activities, never get punishment due to skipping classes, punishment never makes guilty, easiness of getting fake illness statements, subject of lectures, parents' support to not attend the class, long time duration of interlude between classes, family conflicts, allowed to attend to exam even if never attend the class, easiness of double signature of attendance list, less control from parents, and inconsistence implementation of sanctions.

Research that was conducted by Romer [14] found that there is link between some class characteristics and absenteeism as follows:

1. Smaller classes, less absenteeism.

2. The more significant the mathematical component of the course, the less absenteeism.

3. There is more absenteeism in introductory class rather than upper level course.

4. The better lecturer's quality, the less absenteeism. 
5. Absenteeism was mainly concentrated in a few students who missed many classes while most students rarely missed classes.

Although Romer [14] mentioned that the smaller the class the fewer students' absenteeism, learning in a large group of classes is still important since the class has more participants to do discussions during the class [15]. Attendance also enables problem-based learning in classes. Schmidt et. at [16] explained that problem-based learning has better professional competence rather than conventional learning. Problem-based learning is an educational strategy using the real-world problem as the basis of the material, which needs the presence of the subjects to get involved, in order to get more knowledge and expand the knowledge that is already known before [17].

\subsection{Learning behavior}

A learning behavior become spontaneous if it is done continuously so that it can affect the academic development [18]. Rimbano and Putri [19] asserted that there are five things that are related to good learning behavior such as: 1) follow the study materials; 2) strengthening subjects' understanding; 3) book reading; 4) doing assignments; 5) studying and preparing for exams. It is important to have proper methods of study that suitable for learning objectives, in order to have academic achievement. Similarly, Suwardjono [20] examined four learning behavior elements such as: 1) paying attention during class; 2) book reading; 3 ) library visits; 4) preparing for exams.

\subsection{Interest in reading}

Learning language consist of speaking, reading, writing, and heeding. Reading itself can be defined as a process and result at the same time. Reading is a complex process that involves not only pronouncing written text, but also involving visual activity, thinking, psycholinguistic, and metacognitive [21]. To sum up, reading is a process for the reader to get the message that the writer wants to deliver through words or oral [22].

Good reading activity is not only an activity to read, but rather to get information. It means that rather only seek for joy, the reader should also have a specific objective in reading, to gain knowledge. In addition, reading is also a communication process. If it is compared with another communication process such as talking, reading is more complex. It is a complex process since it involves thinking activity to understand information through visual sensory to interpret symbols that are put together to deliver meaning from the writer to the reader [21]. Therefore, it can be said that reading activity is a brainy activity to understand symbols (written words).

Interest in reading does not happen spontaneously. It occurs because of a long process of long and continuous habit of reading. According to Rahim [22] interest in reading is a great willingness that goes along with reading efforts. This means that a person who has an interest in reading will actualize the activity by always looking for materials to be read and read them with consciousness. Therefore, it can be said that interest in reading is the preference to the activity of understanding of written language, which is shown by a willingness to concern the activity without being told by someone and with the self-consciousness and motivation from inner self, and it is showed by the willingness to seek materials to be read in order to seek for information.

\subsection{Accounting understanding definition}

Understanding is the ability of someone to get know after it is experienced and memorized. A student is qualified as understand a subject when he or she can give a specific 
description or explanation with his or her own words. Understanding is also a set of stages in thinking that is one level higher than memorization. The ability to understand materials can be categorized into three stages: translate, interpret, and extrapolation [23]. According to Merriam Webster online (2018) understanding is the ability of having the power of comprehensive. Therefore, those who are categorized as understand on accounting are those who expert and understand accounting comprehensively.

The understanding level of accounting of students can be measured by how far they understand about materials that they have studied, where the context on this is focused on accounting subjects that are being taught. The evidence that students understand is not only can be seen by the grade that they get, but also on how they understand the concepts related to accounting subjects. They can be said that are qualified as understand accounting if the knowledge that they get can be implemented in social life as well as used in the professional world as an accountant.

In this study, accounting understanding can be measured by grades for the following accounting subjects:

- Introduction to Accounting

- Intermediate Accounting

- Advanced Accounting

- Auditing

- Accounting Theory

- Management Control System

This study chooses the six accounting subjects since they are considered to be the core subjects in accounting and are used widely in many area of accounting.

\subsection{Hypotheses development}

Prior learning in this study is defined as experiences obtained by a person as the result of joining educational programs in the past. If a person has an accounting educational background, therefore he or she assumed to have better accounting understanding [8]. Therefore, students who took accounting subjects in high school understand accounting better in higher-level education [9]. On the other hand, those who do not have an accounting background since they did not take accounting in high school may have difficulties in understanding accounting. Thus, the following hypothesis can be developed:

\section{H1: Prior accounting learning has a positive influence on accounting understanding}

Attendance allows students to get involved in discussions and interactions. It also stimulates the enhancement of memory in the brain. Class attendance is considered to be a better method rather than only memorizing the class's materials. Therefore, school attendance is important for students since it can help with their understanding of accounting. A previous study by Jameel and Hamdan [7] shows that attendance affects students' performance in understanding accounting, in which $61,6 \%$ of college accounting students believe that attendance helps with their performance. Thus, it can be stated that the hypothesis as follows:

\section{H2: Class attendance has a positive influence on accounting understanding}

Students' learning behavior is impacted by the consciousness of goal congruence between the students and academic institutions. Suwardjono [24] mentioned that study in the higher-level institution is a strategic choice in obtaining the goals. The controlling process is 
more important rather than only see the aspect of grade or mark. If the process is good, the mark or grade given is a logical consequence. Good or bad learning behavior can be seen from how students following the lecture during class, behavior in visiting the library, and behavior in preparing examinations. The better the learning behavior, the better the understanding students will get. Conversely, the worse students' learning behavior, the worse their understanding. Moreover, previous researches by Agustina and Yanti [8] show that students' learning behavior has a positive impact on accounting understanding. Based on the discussed literature, the following hypothesis can be developed:

H3: Learning behavior has a positive influence on accounting understanding.

Learning and studying activities basically start with reading. Interest in reading has an important role in impacting understanding knowledge. In accounting, reading helps the understanding of the business as a whole since accounting is not only a bean counting activity but also an important activity that uses specific skills to provide accounting information for other business activities [25]. Furthermore, a study by Pratiwi [10] found that the interest in reading positively impacts students' accounting understanding.

Therefore, accounting students must have a strong interest in reading in order to have a wide knowledge of accounting concepts, principles, methods, and practices. Thus, it can be stated that the hypothesis as follows:

H4: Interest in reading has a positive influence on accounting understanding

\section{Research methods}

This section explains population and sample, operational definition of variables, data collection and instruments, and data analysis tools employed in this study.

\subsection{Population and sample}

The population of this study is accounting students in Daerah Istimewa Yogyakarta, which is a special region in Indonesia. The samples of this study were accounting students from three higher-education institutions, which are Universitas Islam Indonesia, Universitas Gadjah Mada, and Universitas Muhammadiyah Yogyakarta. The three institutions mentioned are chosen since those universities are among the top universities in Indonesia. The samples of this study were selected by using purposive sampling. The calculation of the number of samples was conducted by using the Slovin formula.

\subsection{Operational definition of variables}

The dependent variable in this study in accounting understanding and the independent variables of this study are prior accounting learning, class attendance, learning behavior, and interest in reading. The variables are measured using questions in the questionnaires and the questions were adopted from previous research as explained in Table 1 below: 
Table 1. Measurement of Independent and Dependent Variables

\begin{tabular}{ll}
\hline Variables & Measurement \\
\hline Prior accounting learning & -High school background \\
{$[9]$} & -Prior experience in learning accounting \\
Class attendance & -Issues whether attendance helps understand better \\
{$[7]$} & -Reason of attendance \\
& -Reason of non-attendance \\
& -Learning behavior in class \\
Learning behavior & -Behavior of preparing for exams \\
[26] & -Reading frequency \\
Interest in reading & -Aims of reading \\
& -Reading materials \\
& -The feeling when reading \\
& -Surrounding affection to read \\
Accounting understanding & -Average of accounting studies grades \\
\hline 8$],[10],[19]$ & \\
\hline
\end{tabular}

In measuring the accounting understanding (dependent variable), the study uses marks of the following accounting subjects: Introduction to Accounting, Intermediate Accounting, Advanced Accounting, Auditing, Accounting Theory, and Management Control Systems. The dependent variable is measured with 4 points scale which has answer options from 1(D) - 4(A). Therefore, the lowest score that can be reached is 1 and the highest score that can be reached is 4 . This study follows measurement by Dara [26] in which Dara divided the scale into four categories as follows:

- $1=1,00-1,75=$ very low level of accounting understanding

- $2=1,76-2,25=$ low level of accounting understanding

- $3=2,26-3,25=$ high level of accounting understanding

- $4=3,26-4,00=$ very high level of accounting understanding

For the measurement of independent variables, this study employed a Likert 5-points scale ranging from strongly agree ( 5 points) to strongly disagree (1 point) for positive statements and a vice versa measurement for negative statements.

\subsection{Data collection}

The questionnaires in this study were distributed online. Table 2 below displays the information on questionnaires distributed online:

Table 2. Questionnaires Distribution

\begin{tabular}{lc}
\hline Questionnaires Distribution & Number of Questionnaires \\
\hline Distributed questionnaires & 200 \\
Returned questionnaires & 165 \\
Uncomplete questionnaires & 11 \\
& 154 \\
\hline
\end{tabular}




\subsection{Data analysis}

Data quality in this study is tested using Cronbach alpha's for reliability and Pearson's correlation coefficient for validity. Descriptive analysis is also conducted to summarise the data set analyzed in this study. A multiple regression analysis is also employed to predict the relationship between independent variables and the dependent variable of this study. Furthermore, to test the hypotheses, this study used t-test. The regression model used in this study is as follows:

$$
\mathrm{Y}=\alpha+\beta 1 \mathrm{X} 1+\beta 2 \mathrm{X} 2+\beta 3 \mathrm{X} 3+\beta 4 \mathrm{X} 4+\mathrm{e}
$$

$\mathrm{Y}=$ Accounting understanding, $\alpha=$ constant,$\beta=$ regression coefficient, $\mathrm{X} 1=$ prior accounting learning, $\mathrm{X} 2$ = class attendance, $\mathrm{X} 3=$ learning behavior, $\mathrm{X} 4=$ interest in reading, $\mathrm{e}=$ errors.

\section{Results and discussion}

This section discusses the statistical analysis results and discussion based on the results. Table 3 below displays the descriptive statistics of the data analyzed in this study.

Table 3. Descriptive statistics

\begin{tabular}{lccccc}
\hline & $\mathrm{n}$ & Min & Max & Mean & Std. Deviation \\
\hline $\begin{array}{l}\text { Accounting } \\
\text { understanding }\end{array}$ & 154 & 2.50 & 4.00 & 3.7381 & .29327 \\
$\begin{array}{l}\text { Prior } \\
\text { accounting }\end{array}$ & 154 & .50 & 4.88 & 3.0714 & 1.18300 \\
$\begin{array}{l}\text { learning } \\
\begin{array}{l}\text { Class } \\
\text { attendance }\end{array}\end{array}$ & 154 & 2.29 & 5.00 & 3.8571 & .61505 \\
$\begin{array}{l}\text { Learning } \\
\text { behavior }\end{array}$ & 154 & 2.33 & 5.00 & 3.6569 & .52644 \\
$\begin{array}{l}\text { Interest in } \\
\text { reading }\end{array}$ & 154 & 1.92 & 5.00 & 3.4780 & .62610 \\
\hline
\end{tabular}

For reliability, the Cronbach's alpha on each of the variables of this study is higher than 0.6 , hence it can be concluded that all items in the questionnaire are reliable. For the validity of the items in the questionnaire, all correlation coefficient from the questionnaire items have r-calculate $>$ r-table $(0.158)$ and $p$-value $<0,05$. Thus, it can be concluded that the items in the questionnaires distributed to the respondents are measuring what they meant to measure.

A multiple regression analysis was conducted to investigate the relationship between the dependent variable and independent variables in this study. Table 4 below shows the analysis results. 
Table 4. Multiple regression snalysis results

\begin{tabular}{lcccc}
\hline Variables & $\begin{array}{l}\text { Regression } \\
\text { Coefficient }\end{array}$ & Stand. Error & t-value & p-value \\
\hline (Constant) & 2.452 & 0.166 & 14.738 & 0.000 \\
Prior accounting & 0.078 & 0.017 & 4.555 & 0.000 \\
learning & & & & \\
Class attendance & 0.086 & 0.035 & 2.486 & 0.014 \\
Learning behavior & 0.127 & 0.042 & 3.030 & 0.003 \\
Interest in reading & 0.071 & 0.034 & 2.073 & 0.040 \\
Multiple R & 0.582 & & & \\
Adjusted R & 0.321 & & & \\
F Statistic & 19.044 & & & \\
p value & 0.000 & & & \\
\hline
\end{tabular}

\subsection{H1 testing}

The first hypothesis investigates whether or not prior accounting learning has a positive influence on students' understanding of accounting. The result shows that $t$ value is 4.555 and $\mathrm{p}$ value is $0.000(0.000<0.05)$, therefore $\mathrm{H} 1$ is supported and prior accounting learning is found to have a positive and significant influence on students' accounting understanding.

\subsection{H2 testing}

The second hypothesis investigates whether or not class attendance has a positive influence on students' understanding of accounting. The result shows that t value is 2.486 and the p-value is $0.014(0.014<0.05)$. Hence, $\mathrm{H} 2$ is supported and students' class attendance has a positive and significant influence on students' accounting understanding.

\subsection{H3 testing}

The third hypothesis examines whether or not learning behavior has a positive influence on students' understanding of accounting. The result shows that value is 3.030 and the $\mathrm{p}$ value is $0.003(0.003<0.05)$. Therefore, H3 is supported by the data. The results imply that students' learning behavior has a positive and significant influence on students' accounting understanding.

\subsection{H4 testing}

The fourth hypothesis examines whether or not interest in reading has a positive influence on students' understanding of accounting. The result shows that $t$ value is 2.073 and the p-value is $0.040(0.040<0.05)$, hence $\mathrm{H} 4$ is supported by the data. The implication is students' interest in reading has a positive and significant influence on students' accounting understanding.

\subsection{Discussion}

The result of the analysis shows that students' prior accounting learning has a positive and significant influence on accounting understanding. This result means the better students previous experience in accounting, the better their accounting understanding. Without having 
accounting basic knowledge, it may be harder to understand accounting subjects. This result is similar to findings from Agustina and Yanti [8] and Lintang [9] who found that students who already learned accounting before - especially those who took social science and accounting in high school - will surely do not find it hard to learn accounting in their undergraduate level.

The result of the analysis shows that students' class attendance has a positive and significant influence on accounting understanding. This result means that the more often students attend classes, the better their accounting understanding and vice versa. This particular finding supports a study by Jameel and Hamdan [7] who found that class attendance has a big impact on students in understanding the accounting subjects.

The result of the data analysis also shows that students' learning behavior has a positive and significant influence on accounting understanding. This result implies that the better students ' behavior when learning, the better their understanding of accounting. This result is similar to findings by Agustina and Yanti [8] who found that students' learning behavior has a positive impact on accounting understanding.

The last result of this study indicates that students' interest in reading has a positive and significant influence on accounting understanding. This result means that the better students interest in reading, the better their accounting understanding. This finding supports findings by Pratiwi [10] who also found that the interest in reading positively impacts students accounting understanding.

\section{Conclusion, recommendations and limitations}

This study found that prior accounting learning, class attendance, learning behavior and interest in reading have a positive and significant influence on student's understanding of accounting. The implications are accounting education providers must consider the abovementioned factors when designing accounting courses at the undergraduate level in order to maximize students' understanding of accounting. Accounting students can also use the findings of this study to design their own study plan. Despite its findings, this study is quite limited since the respondents were only from three universities in Daerah Istimewa Yogyakarta. Future research can use more samples from universities in different regions in Indonesia in order to increase the external validity of the study.

\section{References}

[1] Marriot, P., Edwards, J. R., \& Mellett, H. J: Introduction to Accounting 3rd Edition. London: Sage Publications (2002).

[2] Wasistha, G. H.: Competencies of Chartered Accountant IAI. In Kompetensi Akuntan Professional. Retrieved from http://www.iaiglobal.or.id/v03/files/file publikasi/Prodi\%20PPAK Dr. $\% 20$ Gede $\% 20$ Harja $\% 2$ 0W.pdf (2018).

[3] Budhiyanto, S. J., \& Nugroho, I. P.: Pengaruh Kecerdasan Emosional terhadap Tingkat Pemahaman Akuntansi. Issues in Jurnal Ekonomi Bisnis, 5(2), 260-281. (2004). 
[4] Lunenburg, F. C.: Self-Efficacy in the Workplace: Implications for Motivation and Performance. Issues in International Journal of Management, Business, and Administration, 14(1), 101-106. (2011).

[5] Suwardjono.: Perilaku Belajar di Perguruan Tinggi. Issues on Jurnal Akuntansi STIE YKPN Yogyakarta, (pola pengajaran alternatif), 1-14. (2004).

[6] Clay, T., \& Breslow, L.: Why students don't attend class. MIT Newsletter, XVIIII, pp. 6-7. (2006).

[7] Jameel, S. H., \& Hamdan, A.: Effects of Students' Attendance on Accounting Students' Performance. Issues in International Journal of Business and Management Review, 3(5), 79-93. (2015).

[8] Agustina, \& Yanti, D. M.: Analisis Faktor-Faktor Yang Mempengaruhi Tingkat Pemahaman Akuntnasi Mahasiswa Jurusan Akuntansi STIE MIKROSKIL Medan. Issues in Jurnal Wira Ekonomi Mikroskil, 5(1), 11-20. (2015).

[9] Lintang, E.: Analisis Tingkat Pemahaman Mahasiswa Akuntansi terhadap Konsep Dasar Akuntansi. Undergraduate Thesis, Fakultas Ekonomi, Universitas Islam Indonesia, Yogyakarta. (2014).

[10] Pratiwi, H. H.: Pengaruh Kecerdasan Emosional, Minat Membaca, dan Budaya Terhadap Tingkat Pemahaman Akuntansi dengan Kepercayaan Diri Sebagai Variabel Moderasi (Studi Empiris pada Mahasiswa Akuntansi Perguruan Tinggi di DIY). Undergraduate Thesis, Universitas Muhammadiyah Yogyakarta, Accounting Department, Yogyakarta. (2016).

[11] Bhoje, G.: The Importance of Motivation in an Educational Environment. Solapur: Laxmi Book Production. (2015).

[12] Sar'I, M., Irsyadsayh, M., \& Djamil, N.: Analisis Tingkat Pemahaman Mahasiswa Akuntansi terhadap Konsep Dasar Akuntansi (Studi Empiris Pada Mahasiswa S1 UIN Suska Riau Yang Berasal Dari Latar Belakang Sekolah Menengah Yang Berbeda). Proceeding of Simposium Nasional Akuntansi XIII Purwokerto, (pp. 0-23). Purwokerto. (2010).

[13] Prihartanto, T.: Faktor-Faktor yang Mempengaruhi Perilaku Membolos pada Mahasiswa. Undergraduate Thesis. Universitas Katolik Soegijapranata, Semarang. (2009).

[14] Romer, D.: Do students go to class? Should they? Issues in Journal of Economic Perspectives, 7(3), 167-174. (1993).

[15] Lisiswanti, R., \& Saputra, O.: Faktor-Faktor yang Mempengaruhi Ketertarikan Mahasiswa Kuliah Dalam Kelas Besar. Issues in Jurnal Kedokteran Universitas Lampung, 5(9), 115-118. (2015).

[16] Schmidt, H., Vermeulen, L., \& Van Der Molen, H. T.: Long Term Effect of Problem-based Learning: a comparison of competencies acquired by graduates of problem based and a conventional medical school. Issues in Med Edu, 40(6), 562-567 (2006).

[17] Kwann, A.: Problem-based Learning. In T. a. Routledge, M. Tight, K. H. Mok, J. Huisman, \& C. C. Morphew (Eds.), The Routledge International Handbook of Higher Education (pp. 91-108). Oxford: Routledge. (2009).

[18] Hanifah, \& Abdullah, S.: Pengaruh Perilaku Belajar terhadap Prestasi Akademik Mahasiswa Akuntansi. Issues in Media Riset Akuntansi, Auditing, Dan Informasi, 1(3), 63-68. (2001).

[19] Rimbano, D., \& Putri, M. E.: Pengaruh Kecerdasan Emosional, Kecerdasan Spiritual, dan Perilaku Belajar Terhadap Tingkat Pemahaman Akuntansi. Issues in Jurnal Ilmiah Orasi Bisnis, 15(1), 11-32. (2016).

[20] Suwardjono.: Perilaku Belajar di Perguruan Tinggi Gagasan Pengembangan Profesi dan Pendidikan Akuntansi di Indonesia. Yogyakarta: BPFE. (1992).

[21] Tarigan, H. G.: Membaca Sebagai Suatu Keterampilan Berbahasa. Bandung: Angkasa. (1990).

[22] Prabantantyo, N. K.: Korelasi Minat Membaca di Perpustakaan Sekolah dengan Prestasi Belajar Siswa Kelas IV SD di Kecamatan Pengasih Kabupaten Kulon Progo. Undergraduate Thesis, Universitas Negeri Yogyakarta, Yogyakarta. (2012).

[23] Rahim, F.: Pengajaran Membaca di Sekolah Dasar (2nd ed.). Jakarta: Sinar Grafika. Ranking Web of Universities. (2018) In Webometrics. Retrieved from http://www.webometrics.info/en/Asia/indonesia\%20 (2008). 
[24] Putro, R. K., \& Wijaya, A.: Pengaruh Kecerdasan Emosional, Perilaku Belajar, Pengetahuan Akuntansi SMA, dan Minat Belajar terhadap Pemahaman Akuntansi (Studi pada Mahasiswa 2012 \& 2013 Program S1 Akuntansi Universitas Brawijaya). Undergraduate Thesis, Universitas Brawijaya, Malang. (2013).

[25] Hariyoga, S., \& Supriyanto, E.: Pengaruh Kecerdasan Emosional, Perilaku Belajar, dan Budaya terhadap Pemahaman Akuntansi dengan Kepercayaan Diri sebagai Variable Pemoderasi. Proceeding of Simposium Nasional Akuntansi XIV, (pp. 21-22). Aceh. (2011).

[26] Dara, J. P.: Pengaruh kecerdasan emosional, kecerdasan spiritual, kecerdasan sosial, dan perilaku belajar terhadap pemahaman akuntansi. Skripsi. Fakultas Ekonomi. Universitas Islam Indonesia. (2013). 